\title{
Influence of the availability of iron during hypoxia on the genes associated with apoptotic activity and local iron metabolism in rat $\mathrm{H9C} 2$ cardiomyocytes and L6G8C5 skeletal myocytes
}

\author{
MAGDALENA DZIEGALA ${ }^{1}$, MONIKA KASZTURA ${ }^{2}$, KAMIL KOBAK $^{3}$, JACEK BANIA $^{4}$, \\ WALDEMAR BANASIAK $^{5}$, PIOTR PONIKOWSKI ${ }^{2,5}$ and EWA A. JANKOWSKA ${ }^{3,5}$ \\ ${ }^{1}$ Students' Scientific Organization, Department of Heart Diseases; \\ ${ }^{2}$ Department of Heart Diseases, Wrocław Medical University, 50-367 Wrocław; \\ ${ }^{3}$ Laboratory for Applied Research on Cardiovascular System, Department of Heart Diseases, \\ Wrocław Medical University, 50-981 Wrocław; ${ }^{4}$ Department of Food Hygiene and Consumer Health, \\ Wrocław University of Environmental and Life Sciences, 50-375 Wrocław; \\ ${ }^{5}$ Centre for Heart Diseases, Military Hospital, 50-981 Wrocław, Poland
}

Received March 26, 2016; Accepted August 4, 2016

DOI: $10.3892 / \mathrm{mmr} .2016 .5705$

\begin{abstract}
The differential availability of iron during hypoxia is presumed to affect the functioning of cardiac and skeletal myocytes. Rat H9C2 cardiomyocytes and L6G8C5 myocytes were cultured for $48 \mathrm{~h}$ in normoxic or hypoxic conditions at the optimal, reduced or increased iron concentration. The mRNA expression levels of markers of apoptosis [B-cell lymphoma-2 (Bcl2; inhibition) and Bcl-2-activated $\mathrm{X}$ protein (Bax; induction)], atrophy (Atrogin), glycolysis (pyruvate kinase $2 ; P K M 2)$ and iron metabolism [transferrin receptor 1 ( $T f R l$; iron importer), ferroportin 1 (FPNl; iron exporter), ferritin heavy chain ( $F T H$; iron storage protein) and hepcidin (HAMP; iron regulator)] were determined using reverse transcription-quantitative polymerase chain reaction, and cell viability was measured using an tetrazolium reduction assay. Cardiomyocytes and myocytes, when exposed to hypoxia, demonstrated an increased $\mathrm{Bax} / \mathrm{Bcl}-2$ gene expression ratio $(\mathrm{P}<0.05)$. Additional deferoxamine $(\mathrm{DFO})$ treatment resulted in further increases in $\mathrm{Bax} / \mathrm{Bcl}-2$ in each cell type $(\mathrm{P}<0.001 \mathrm{each})$ and this was associated with the $15 \%$ loss in viability. The analogous alterations were observed in
\end{abstract}

Correspondence to: Professor Ewa A. Jankowska, Centre for Heart Diseases, Military Hospital, 5 Weigla Street, 50-981 Wrocław, Poland

E-mail: ewa.jankowska@umed.wroc.pl

Abbreviations: PKM2, pyruvate kinase isoform 2; TfR1, transferrin receptor type 1; FPN1, ferroportin type 1; HAMP, hepcidin; FTH, ferritin heavy chain; DFO, deferoxamine; AFC, ammonium ferric citrate

Key words: iron deficiency, iron excess, hypoxia, apoptotic activity, iron metabolism genes, cardiomyocyte, skeletal myocyte both cell types upon ammonium ferric citrate (AFC) treatment during hypoxia; however, the increased $\mathrm{Bax} / \mathrm{Bcl}-2$ ratio and associated viability loss was lower compared with that in case of DFO treatment $(\mathrm{P}<0.05$ each). Under hypoxic conditions, myocytes demonstrated an increased expression of PKM2 $(\mathrm{P}<0.01)$. Additional DFO treatment caused an increase in the mRNA expression levels of $P K M 2$ and Atrogin-1 $(\mathrm{P}<0.001$ and $\mathrm{P}<0.05$, respectively), whereas $\mathrm{AFC}$ treatment caused an increased mRNA expression of $P K M 2$ $(\mathrm{P}<0.01)$ and accompanied decreased mRNA expression of Atrogin $-1 \quad(\mathrm{P}<0.05)$. The expression augmentation of PKM2 during hypoxia was greater upon low iron compared with that of ferric salt treatment $(\mathrm{P}<0.01)$. Both cell types upon DFO during hypoxia demonstrated the increased expression of TfR 1 and HAMP (all $\mathrm{P}<0.05)$, which was associated with the increased $\mathrm{Bax} / \mathrm{Bcl}-2$ ratio (all $\mathrm{R}>0.6$ and $\mathrm{P}<0.05$ ). In conclusion, during hypoxia iron deficiency impairs the viability of cardiomyocytes and myocytes more severely compared with iron excess. In myocytes, during hypoxia iron may act in a protective manner, since the level of atrophy is decreased in the iron-salt-treated cells.

\section{Introduction}

Optimal oxygen supply is of the utmost importance for the effective functioning of cells with high energy demand, including cardiomyocytes and myocytes, since their metabolism relies on the oxidative pathway (1-3). Nonetheless, their productive performance is critically contributed to by another agent, namely iron (4). As an essential component of co-factors present both in oxygen carriers and in numerous enzymes of oxidative metabolism, iron constitutes the cornerstone of tissue oxygen supply and energy generation (4-7). Notably, the experimental data demonstrates that hypoxia and an iron deficient state may have to some extent, similar consequences in both cardiac and skeletal myocytes at the molecular level, including impairment of the mitochondrial electron transport 
chain and triggering a shift from oxidative to glycolytic metabolism (8-13).

Previous evidence suggests that the optimal iron homeostasis is crucial for patients with various cardiovascular disorders, including coronary artery disease (14) and heart failure (15-17), in which hypoxia is an important causative factor. Notably, data from previous clinical studies confirmed the beneficial effects of iron therapy in non-anaemic iron-deficient patients with heart failure accompanied by skeletal myopathy (18-23). To date, the majority of studies have investigated the molecular links between hypoxia and iron metabolism in different cells involved in systemic iron homeostasis, including macrophages, enterocytes, hepatocytes or erythroid precursor cells (24-28); however, very little attention have been given to gain an insight into molecular associations between oxygen and iron availability in the cells of cardiac or skeletal muscle tissues. Robach et al (29) investigated the influence of hypoxia on the expression of selected genes of iron metabolism, namely transferrin receptor and L-ferritin (FTH), in skeletal muscle; however, the studies involved human subjects exposed to high-altitude hypoxia where it was difficult to obtain changing experimental conditions.

Since hypoxic conditions are difficult to introduce and manipulate in humans and animals, the present study used cell culture models. The aim of the present study was to investigate the associations between selected genes involved in iron metabolism and cellular apoptotic activity assessed in diverse oxygen and iron availabilities in two rat cell lines: Cardiomyocytes (H9C2) and skeletal myocytes (L6G8C5).

\section{Materials and methods}

Cell culture. Rat H9C2 cardiomyocytes and rat L6G9C2 (L6) skeletal myocytes (Sigma-Aldrich, St. Louis, MO, USA) were grown in Dulbecco's modified Eagle's medium (DMEM; Sigma-Aldrich), supplemented with $10 \%$ fetal bovine serum (FBS; Invitrogen; Thermo Fisher Scientific, Inc., Waltham, MA, USA), $2 \mathrm{mmol} / 1$ glutamine, $10^{4}$ diluted $10,000 \mathrm{U} / \mathrm{ml}$ penicillin and $10 \mathrm{mg} / \mathrm{ml}$ streptomycin (all from Sigma-Aldrich). For passaging, the cells were washed with phosphate-buffered saline (PBS; without $\mathrm{Ca}^{2+}$ and $\mathrm{Mg}^{2+}$ ) and were released by trypsinization (Sigma-Aldrich). The cells were maintained according to manufacturer's protocols.

Experimental schedule. Rat $\mathrm{H} 9 \mathrm{C} 2$ cardiomyocytes and rat L6G9C2 skeletal myocytes were cultured with an addition of deferoxamine (DFO; Sigma-Aldrich) or ammonium ferric citrate (AFC; Sigma-Aldrich) in order to change iron accessibility in hypoxia for those cells in the cultured medium during hypoxia treatment for $48 \mathrm{~h}$. DFO is a selective iron chelator commonly used in the cell culture studies. It has been reported that addition of DFO into the culture medium reduces iron concentration both in the cellular environment and inside the cell, since DFO can be taken up by fluid phase endocytosis (30). AFC was applied in cell culture studies in order to induce intracellular iron accumulation $(31,32)$.

Modulation of iron concentration in the cellular environment. H9C2 and L6 cells were seeded at $0.3 \times 10^{6}$ cells/well in a volume of $2 \mathrm{ml}$ in 6 -well plates. The cells were cultured under hypoxic conditions $\left(1 \% \mathrm{O}_{2}, 5 \% \mathrm{CO}_{2}, 94 \% \mathrm{~N}_{2}\right)$, which were generated in a standard cell culture incubator by displacing $\mathrm{O}_{2}$ with infusion of $\mathrm{N}_{2}$, which was supplied by an external high-pressure liquid nitrogen tank, in differential iron availability in the growth media for $48 \mathrm{~h}$. The cells were separated into three groups: i) Optimal iron concentration (standard iron concentration in DMEM with $10 \%$ FBS); ii) reduced iron concentration (iron chelation using $100 \mu \mathrm{M} \mathrm{DFO}$ ); iii) increased iron concentration (supplementation with $200 \mu \mathrm{M}$ AFC). The compounds were added to the cells from 1,000X concentrated stocks diluted in culture medium.

Assessed parameters. Multiple parameters were assessed during the present study. These parameters reflected the cellular condition and iron status assessed in the states of different iron availability in culture medium of H9C2 and L6 lines. These parameters were looking at the expression levels of various genes in the following processes: i) Apoptosis, including B-cell lymphoma $(\mathrm{Bcl})$-2-associated $\mathrm{X}$ protein (Bax; inductor) (33), Bcl-2 (inhibitor) (34) and the Bax/Bcl-2 gene expression ratio (35); ii) proteolysis, including Atrogin-1, which is a marker of protein degradation in myocytes and a marker of muscle atrophy (36); iii) glycolysis, including pyruvate kinase (PKM2; marker of non-oxidative metabolism) (37); iv) intracellular iron metabolism, including transferrin receptor type 1 (TfR1; cellular iron importer) (38), ferroportin (FPNI; cellular iron exporter) (39), FTH heavy chain (iron storage protein) (40) and hepcidin (HAMP; iron metabolism regulator protein) (41).

Cell viability tetrazolium reduction assay (MTS). The MTS assay is a colorimetric method used to determine the number of viable and metabolically active cells in proliferation and cytotoxicity assays, as previously described (42). MTS assays were performed, according to manufacturer's protocol (CellTiter 96 ${ }^{\circledR}$ AQueous One Solution Cell Proliferation Assay; Promega Corporation, Madison, WI, USA). Briefly, $2 \times 10^{5}$ H9C2 or L6 cells were seeded into each well of 96 -well plates and were treated for $48 \mathrm{~h}$ with DFO, AFC or PBS (control) in hypoxia or in normoxia, as described above. A total of $20 \mu \mathrm{l}$ CellTiter $96^{\circledR}$ AQueous One Solution reagent was added to each well and the absorbance at $490 \mathrm{~nm}$ was measured after $2 \mathrm{~h}$ incubation in $37^{\circ} \mathrm{C}$ (KCjunior ${ }^{\mathrm{TM}}$; BioTek Instruments, Inc., Winooski, VT, USA). The viability of the control cells was treated as $100 \%$.

Reverse transcription-quantitative polymerase chain reaction $(R T-q P C R)$. The total RNA was prepared from $\mathrm{H} 9 \mathrm{C} 2$ or L6 cells harvested from 6-well tissue culture plates using the RNeasy Fibrous Tissue Mini kit (Qiagen, Hilden, Germany), according to the manufacturer's protocol. The protocol included an on-column DNase digestion to remove the genomic DNA. First-strand cDNA was synthesized using a SuperScript III First-Strand Synthesis system with oligo(dT)20 primer (Invitrogen; Thermo Fisher Scientific, Inc.).

Based on the rat genomic and cDNA sequences the following primers were used: $B c l-2$, forward: 5'-AGCATG CGACCTCTGTTTGA-3' and reverse 5'-TCACTTGTG GCCCAGGTATG-3'; Bax, forward: 5'-TGGCGATGAACT GGACAACA-3' and reverse: 5'-CACGGAAGAAGACCT CTCGG-3'; Atrogin-1 forward: 5'AGCTTGTGCGATGTT ACCCA-3' and reverse 5'-GAGCAGCTCTCTGGGTTGTT-3'; 
PKM2, forward: 5'-TTAGGCCAGCAACGCTTGTA-3' and reverse: 5'-AGCTGGGCTCTATTGCATGT-3'; TfR I, forward: 5'-GAGACTACTTCCGTGCTACTTC-3' and reverse: 5'-TGG AGATACATAGGGTGACAGG-3'; FPN1, forward: 5'-TCG GTCTTTGGTCCTTTGATTTG-3' and reverse 5'-GGCTGA CTTTCATCTGTAACTTCC-3'; $F T H$, forward: 5'-GCCAAA TACTTTCTCCATCAATCTC-3' and reverse: 5'-CCGCTC TCCCAGTCATCAC-3'; HAMP, forward: 5'-GCAACAGAC GAGACAGACTAC-3' and reverse 5'-GCAACAGAGACCACAGGAG-3'. The primers were designed with Molecular Beacon Software (Bio-Rad Laboratories, Inc., Hercules, CA, USA). The primers spanned exon junctions to prevent the amplification of genomic DNA. The reference genes, Actb and I8S-RNA, were selected for normalization of experimental conditions by means of geNorm analysis (PrimerDesign Ltd., Southampton, UK).

All samples were performed in triplicates. The qPCR assay was performed on the CFX Connect Real-Time PCR Detection system. The specificity of PCR was determined by melting curve analysis for each reaction. The amplification efficiency was estimated by running serial dilutions of a template. Successive dilutions were plotted against the appropriate $\mathrm{Cq}$ values to generate a standard curve. The slope calculated from the standard curve was used to determine the amplification efficiency (E) according to the formula: $\mathrm{E}=10-1 /$ slope. The amplification efficiencies for the target amplicons, $a c t b$ and 18srna, were not comparable and the Pfaffl method was used to determine the relative expression (43).

Statistical analysis. The data are presented as the mean \pm standard deviation, unless otherwise indicated. Mann-Whitney $U$ Test was used to compare the groups. All molecular assessments were performed in triplicates. R-value is a correlation coefficient between the expression of iron metabolism genes in three states of iron concentrations and the $B a x / B c l-2$ gene expression ratio in those conditions. $\mathrm{P}<0.05$ was considered to indicate a statistically significant difference.

\section{Results}

Effects of hypoxia on the viability and apoptotic activity of cardiomyocytes and myocytes. Low oxygen treatment reduced the viability of cardiomyocytes and myocytes by 11 and $12 \%$, respectively, as compared with the untreated cells $(\mathrm{P}<0.01$ each). In each cell type, the decrement in viability was associated with an increased $\mathrm{Bax} / \mathrm{Bcl}-2$ gene expression ratio $(\mathrm{P}<0.05)$, reflecting an enhanced susceptibility of cardiomyocytes and myocytes to cellular programmed death (Fig. 1).

Bax/Bcl-2 ratio is associated with the loss of viability of cardiomyocytes and myocytes during hypoxia with concomitant reduced or increased iron availability. In both cardiomyocytes and myocytes, the exposition to low iron availability during hypoxia caused, as compared with the cells cultured during hypoxia and optimal iron concentration, a 15\% loss in viability in each of the cell lines $(\mathrm{P}<0.01$; Fig. $1 \mathrm{~A})$, and this change was associated with an increase in $\mathrm{Bax} / \mathrm{Bcl}-2$ gene expression ratio $(\mathrm{P}<0.001$; Fig. 1B). Likewise, both $\mathrm{H} 9 \mathrm{C} 2$ and L6 cells demonstrated an increase in $\mathrm{Bax} / \mathrm{Bcl}-2$ gene expression ratio $(\mathrm{P}<0.05$ and $\mathrm{P}<0.01$; Fig. 1B) during hypoxia, when exposed to the elevated iron availability, which was associated with 10 and $11 \%$ loss in viability in cardiomyocytes and myocytes, respectively ( $\mathrm{P}<0.01$; Fig. 1A). Notably, in each cell type during hypoxia, the increase in the $\mathrm{Bax} / \mathrm{Bcl}-2$ ratio (Fig. 1B) and associated viability loss (Fig. 1A) were greater upon exposure to low iron availability compared with that in the case of AFC treatment ( $\mathrm{P}<0.05$ each).

Effects of hypoxia with concomitant optimal, reduced or increased iron availability on tissue-specific expression of genes involved in energy metabolism and proteolysis in myocytes. Hypoxic conditions of L6 cell culture caused an increase in the expression of $P K M 2$, which responsible for the rate-limiting step of glycolysis, when compared with cells cultured in normoxia $(\mathrm{P}<0.01)$. Myocytes exposed to DFO during hypoxia demonstrated increased mRNA expression levels of $P K M 2$ and Atrogin- $1(\mathrm{P}<0.001$ and $\mathrm{P}<0.05$, respectively) as compared with the cells cultured in normal iron concentration, suggesting the further enhancement of non-oxidative glycolytic pathway and protein degradation in the cells. The different changes were observed in myocytes treated with $\mathrm{AFC}$, since the increase in the expression of PKM2 $(\mathrm{P}<0.01)$ was accompanied by a decrease in the mRNA expression of Atrogin-1 $(\mathrm{P}<0.05)$ as compared with the cells cultured in optimal iron concentration. The augmented expression of $P K M 2$ in myocytes during hypoxia was greater upon low iron availability compared with during ferric salt treatment $(\mathrm{P}<0.01)$. Notably, the expression of Atrogin-1 during hypoxia and concomitant elevated iron availability was decreased as compared with cells cultured in hypoxia and normal or decreased iron concentration $(\mathrm{P}<0.05$ and $\mathrm{P}<0.01$, respectively; Fig. 2).

Effects of hypoxia with concomitant optimal, reduced or increased iron availability on the expression of genes involved in iron influx and efflux in cardiomyocytes and myocytes. Both L6 and $\mathrm{H} 9 \mathrm{C} 2$ cell lines exposed to hypoxia demonstrated, as compared with the cells cultured in normoxia, a decrease in the expression TfR1 $(\mathrm{P}<0.05$ each) and FPN1 $(\mathrm{P}<0.05$ and $\mathrm{P}<0.01$, respectively).

The addition of DFO to the culture medium of cardiomyocytes and myocytes during hypoxia caused an increased expression of TfRI ( $\mathrm{P}<0.01$ and $\mathrm{P}<0.001$, respectively), reflecting iron demand, thus facilitated entrance of iron to the cells. However, this did not affect the expression of FPNl compared with the cells cultured in normal iron concentration.

The AFC treatment of cardiomyocytes and myocytes during hypoxia resulted in a decreased and increased, respectively, expression of $T f R 1$ ( $\mathrm{P}<0.05$ each). Additionally, this resulted in an increased expression of FPN1 ( $\mathrm{P}<0.05$ each) in each cell line. Under hypoxic conditions with concomitant changing iron availability, the myocytes demonstrated low expression of $F P N 1$ when compared with the cells cultured in normoxia $(\mathrm{P}<0.01)$ (Fig. 3A and B).

Effects of hypoxia with concomitant optimal, reduced or increased iron availability on the expression of the iron storage gene in cardiomyocytes and myocytes. Low oxygen treatment of L6 cells caused, as compared with cells cultured 
A

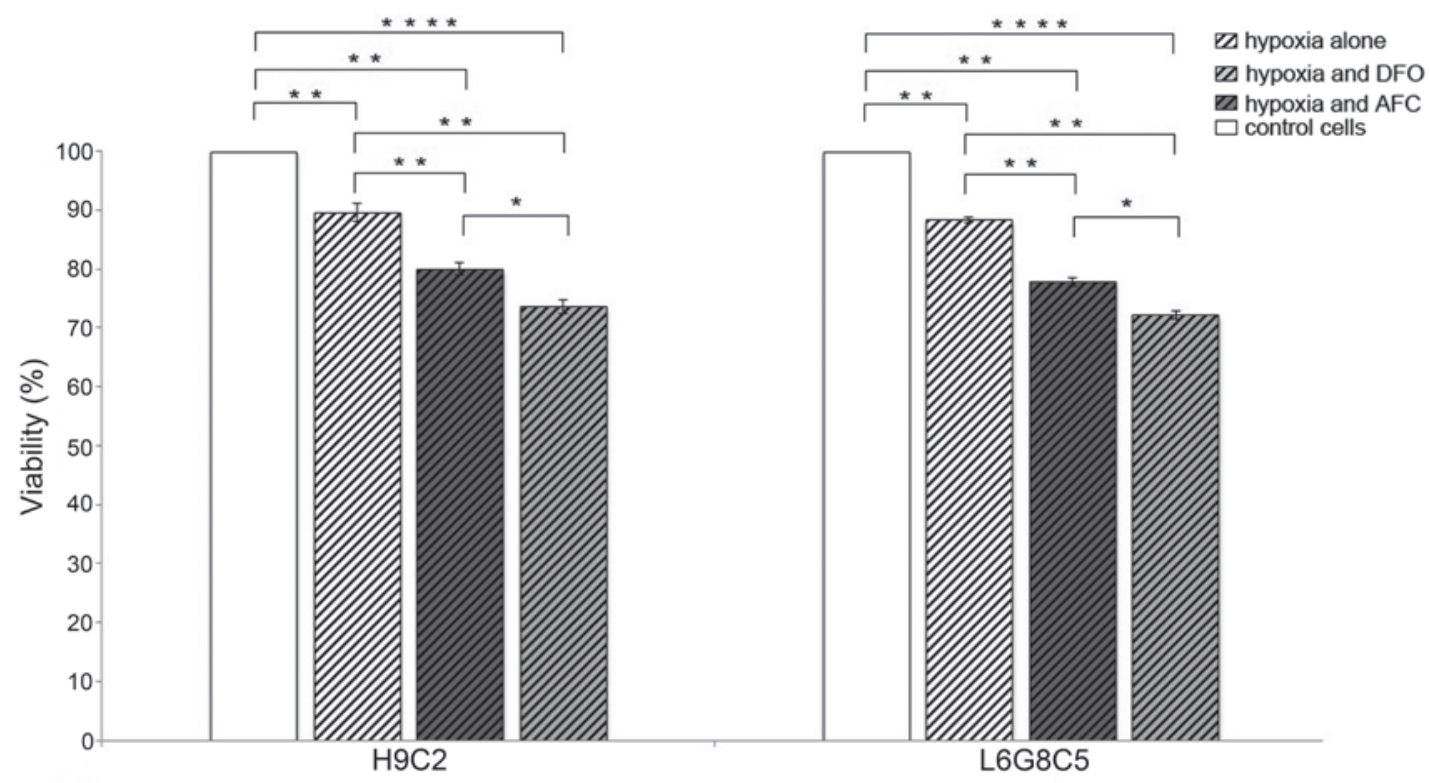

B $B a x / B c l-2$ ratio

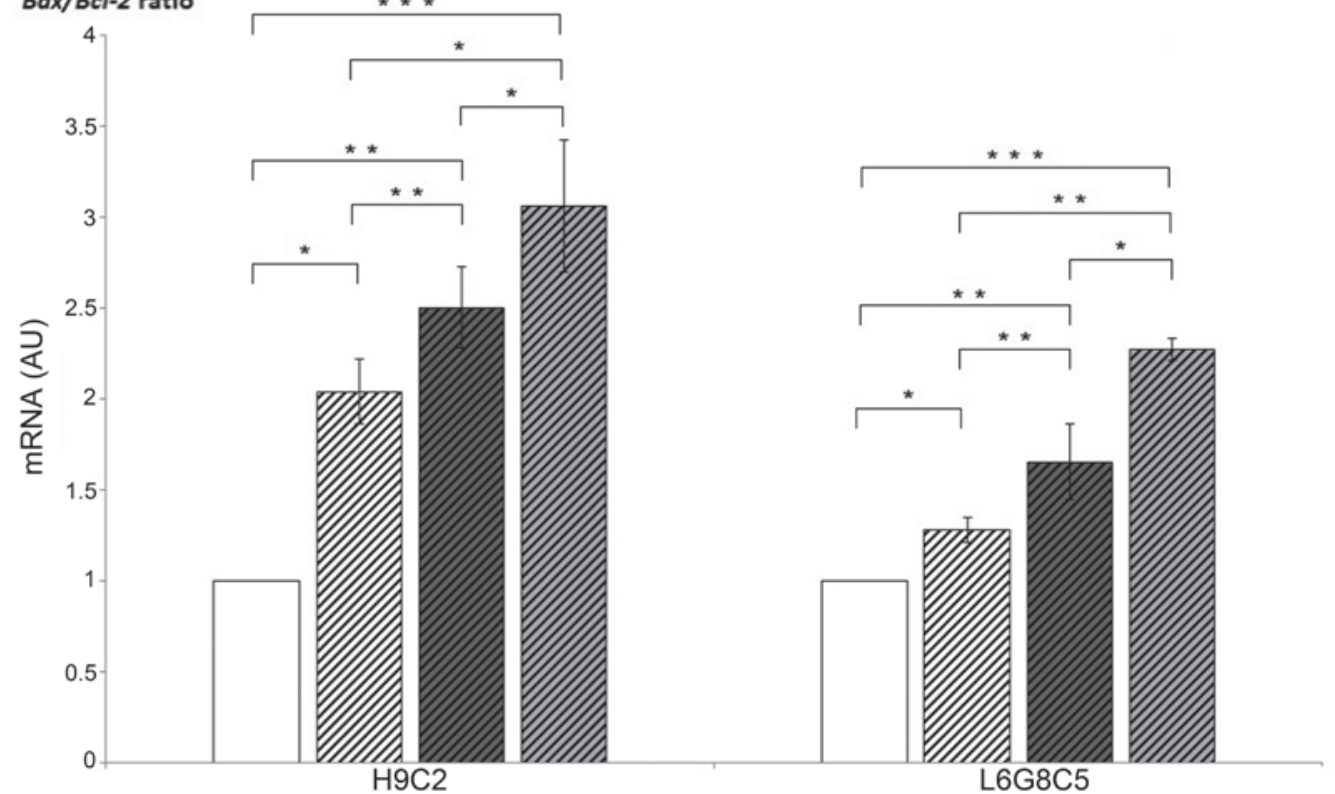

Figure 1. (A) A tetrazolium reduction assay was performed to assess the viability of H9C2 and L6G8C5 cells exposed to hypoxia alone, hypoxia and DFO or hypoxia and $\mathrm{AFC}$ at $48 \mathrm{~h}$. (B) Bax/Bcl-2 mRNA expression ratio was determined by reverse transcription-quantitative polymerase chain reaction in $\mathrm{H} 9 \mathrm{C} 2$ and L6G8C5 cells exposed to hypoxia alone, hypoxia and DFO or hypoxia and AFC. Control cells were cultured in normoxia and were not treated with AFC nor DFO. The data are presented as the mean \pm standard deviation $\left({ }^{*} \mathrm{P}<0.05 ;{ }^{* * *} \mathrm{P}<0.01 ;{ }^{* * * *} \mathrm{P}<0.001 ;{ }^{* * * * *} \mathrm{P}<0.0001\right.$, compared with the control). DFO, deferoxamine; $\mathrm{AFC}$, ammonium ferric citrate; Bcl, B-cell lymphoma; Bax, Bcl-2-asscoiated X protein.

in normoxia, an increased expression of the iron storage gene, FTH $(\mathrm{P}<0.05)$. Exposure to DFO of cardiomyocytes during hypoxia resulted, as compared with hypoxia-treated controls, in unchanged mRNA expression of $F T H$, while hypoxic culture of L6 cells exposed to low iron demonstrated an increase in the expression of the iron storage gene $(\mathrm{P}<0.01)$.

The different pattern of changes was observed upon ferric salt treatment during hypoxia. An increased expression of FTH in both cardiomyocytes and myocytes was observed compared with the cells cultured in normal iron concentration $(\mathrm{P}<0.05$ and $\mathrm{P}<0.01$, respectively) (Fig. 3C).

Effects of hypoxia with concomitant optimal, reduced or increased iron availability on the expression of iron regulator in cardiomyocytes and myocytes. Low oxygen treatment of H9C2 and L6 cells caused an increment in the expression of iron regulator, HAMP $(\mathrm{P}<0.05$ and $\mathrm{P}<0.01$, respectively). An addition of DFO to the culture medium of both studied cell lines during hypoxia caused a further increase in the expression of HAMP $(\mathrm{P}<0.05$ and $\mathrm{P}<0.001)$ as compared with the cells cultured in a normal iron concentration. The exposition of cardiomyocytes and myocytes to AFC treatment in hypoxia resulted in an unchanged or a decreased expression of HAMP $(\mathrm{P}<0.01)$ (Fig. 3D).

An increased expression of iron-related genes in a low iron state during hypoxia is associated with an increased apoptotic activity of cardiomyocytes and myocytes. In both 
A
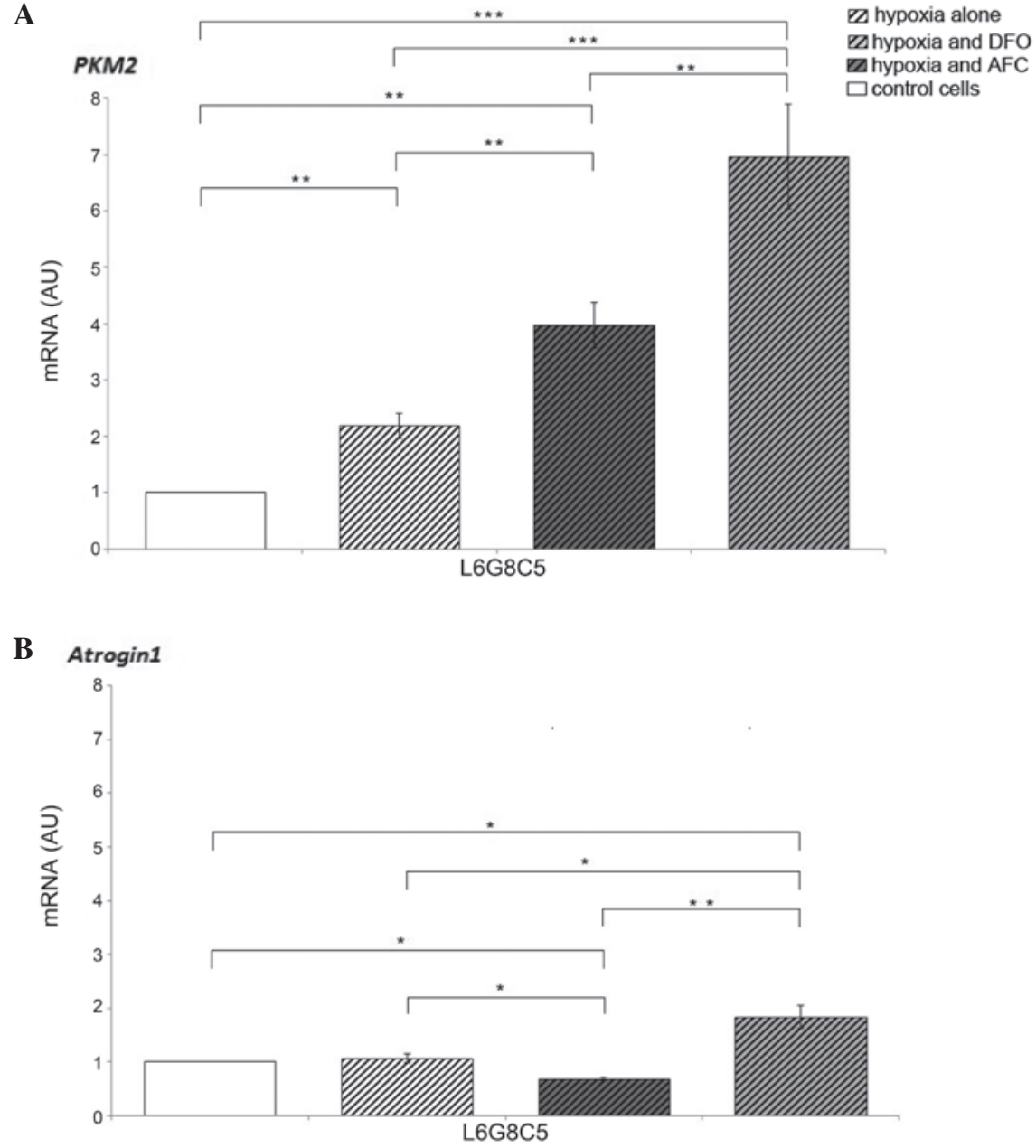

Figure 2. mRNA expression levels of (A) PKM2 and (B) atrogin-1 in L6G8C5 cells exposed to hypoxia alone, hypoxia and DFO or hypoxia and AFC. Control cells were cultured in normoxia and were not treated with AFC or DFO. The data are presented as the mean \pm standard deviation $\left({ }^{*} \mathrm{P}<0.05 ;{ }^{* *} \mathrm{P}<0.01 ;{ }^{* * *} \mathrm{P}<0.001\right.$, compared with the control cells). PKM, pyruvate kinase; DFO, deferoxamine; AFC, ammonium ferric citrate.

cardiomyocytes and myocytes, the expression of genes involved in iron influx $(T f R l)$ and regulation $(H A M P)$ was associated with the $B a x / B c l-2$ gene expression ratio in the whole spectrum of iron status during hypoxia (all $\mathrm{R}>0.6$, $\mathrm{P}<0.05)$. In particular, in a low iron state, the observed upregulation of $T f R l$ and $H A M P$ genes was associated with increased apoptotic activity of each of the cell lines. In addition, L6 cells demonstrated positive correlation between the expression of $\mathrm{FTH}$ and the $\mathrm{Bax} / \mathrm{Bcl}-2$ gene expression ratio $(\mathrm{R}=0.64, \mathrm{P}<0.05)$ (Fig. 4).

\section{Discussion}

The present study compared the influence of increased or reduced iron availability during hypoxia on the viability and apoptotic activity of the cardiac and skeletal myocytes. It was discovered that during hypoxia, the reduced iron concentration had a more negative impact on the viability and functioning of the studied myocytes compared with the elevated iron availability. Furthermore, in these cells cultured during hypoxia and with differential iron availability, the present study was able to investigate changes in the expression of iron turnover genes and to establish associations between the upregulated expression of genes involved in iron influx
(TfR 1$)$ and regulation $(H A M P)$, and the enhanced susceptibility to cellular suicide.

Firstly, the present study demonstrated that hypoxic conditions diminished the viability of cardiomyocytes and myocytes. The accompanying changes in the expression of genes involved in the regulation of apoptosis supported the results from the viability assay, since the gene expression ratio of pro-apoptotic Bax to anti-apoptotic $\mathrm{Bcl}-2$ increased upon low oxygen. Furthermore, it was demonstrated that the exposition of the studied cells to either iron depletion or iron excess during hypoxia hampered the cellular viability and increased $\mathrm{Bax} / \mathrm{Bcl}-2$ gene expression ratio more severely compared with hypoxia treatment alone. This finding was consistent with the study of Walter et al (44) who demonstrated that both iron overload and iron deficiency are detrimental to the functioning of liver mitochondria (44). With this work, besides highlighting the presence of analogous U-shaped association between iron availability and vitality of the studied cells during hypoxia, the present study identified that upon low oxygen conditions, iron deficiency has a more negative impact on the cellular viability and with a greater extent favors apoptosis rather than iron excess.

To the best of our knowledge, the local iron metabolism has only been partially assessed in the cell culture models of 
A

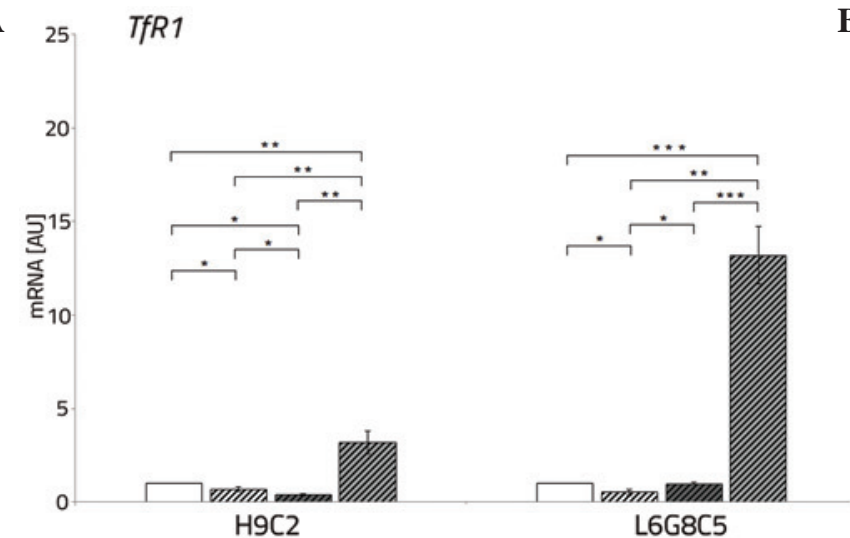

B $25 .-F P N 1$

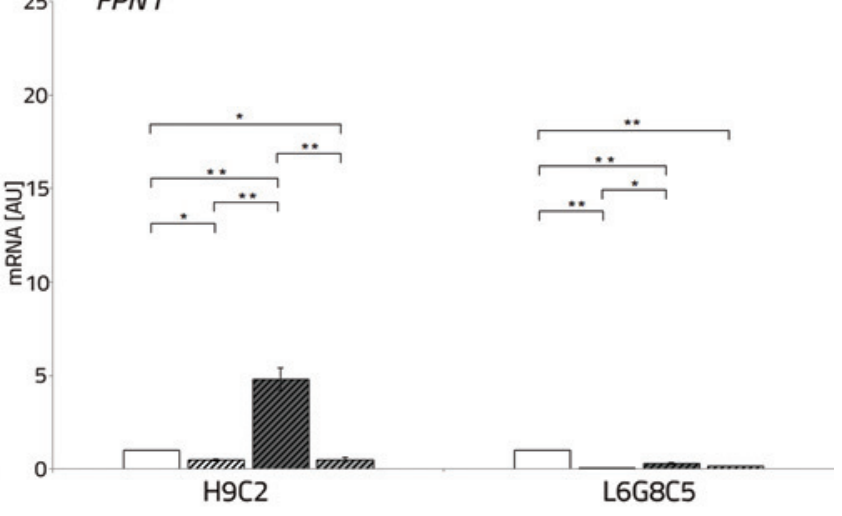

C
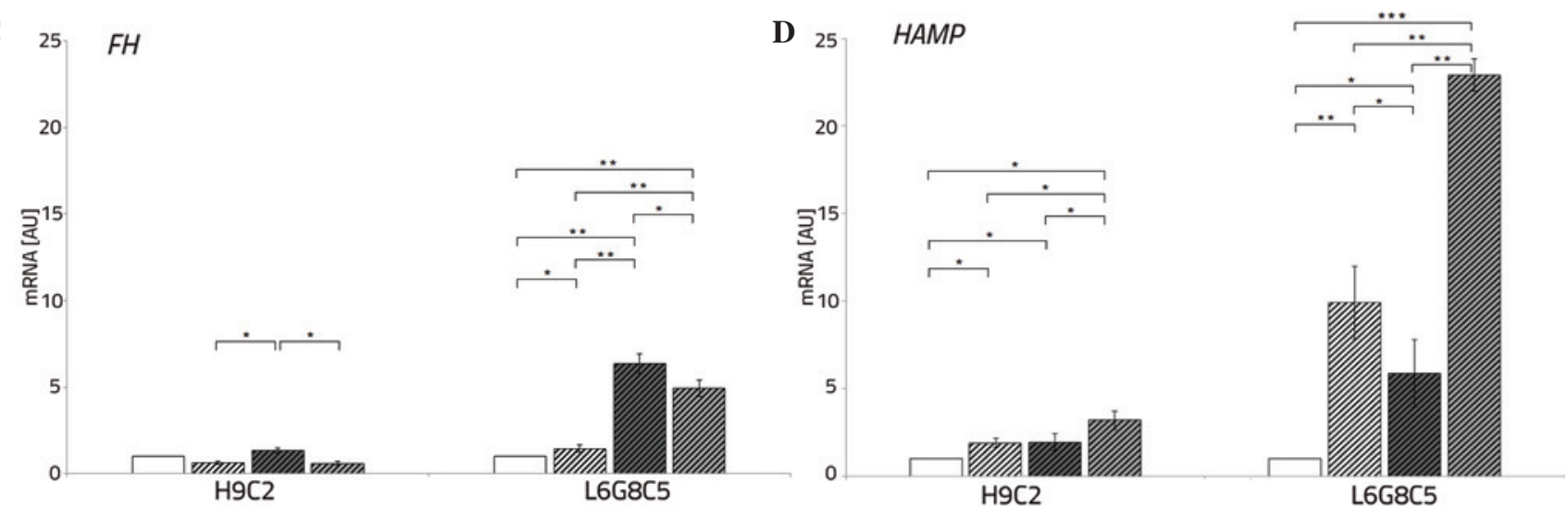

Figure 3. Expression of iron metabolism genes in L6G8C5 and H9C2 cells exposed to hypoxia alone, hypoxia and DFO or hypoxia and AFC for $48 \mathrm{~h}$. The expression levels of (A) TfRI, (B) FPN1, (C) FTH and (D) HAMP were assessed. Control cells were cultured in normoxia and were not treated with AFC or DFO. The data are presented as the mean \pm standard deviation $\left({ }^{*} \mathrm{P}<0.05 ;{ }^{* * *} \mathrm{P}<0.01 ;{ }^{* * *} \mathrm{P}<0.001\right.$, compared with the control). DFO, deferoxamine; AFC, ammonium ferric citrate; TfR1, transferrin receptor type 1; FPN1, ferroportin type 1; FTH, ferritin heavy chain; HAMP, hepcidin.

myocardium and skeletal muscles $(43,44)$. It remains insufficiently investigated upon hypoxia conditions; to date it was explored in skeletal muscle on the model of tissue samples from patients subjected to high-altitude hypoxia (29). The present results are consistent with the study of Robach et al (29), as we observed the hypoxia-driven decrease in the mRNA expression of TfRI and increase in the mRNA expression of $F T H$. However, the present model of cell cultures allowed manipulations within the oxygen and iron availabilities, which were not amenable in humans. Therefore, the present study has provided the first evidence, to the best of our knowledge, of the direct response of iron turnover genes to hypoxia and changing iron availability within the isolated model of cardiomyocytes and skeletal myocytes cultured in vitro.

It was shown that the exposure of cardiomyocytes and myocytes to low oxygen altered the expression of iron turnover genes in each of the cell lines. Notably, these changes vary from the previously reported data, since to date, the studies on the expression of iron-related genes during hypoxia have been performed predominantly in the cells involved in systemic iron homeostasis, including hepatocytes, macrophages, enterocytes or erythroid precursor cells (24-28). For example, the responses of the aforementioned cells to low oxygen involved a hypoxia-driven upregulation of both $T f R I$, in order to enable an enhanced iron uptake by erythrocytes, and FPN1, resulting in the enhanced release of iron into the bloodstream from iron storing and distributing cells (47-49). Furthermore, hypoxia was demonstrated to downregulate the expression of $H A M P$ and to increase the expression of $F T H$ in hepatocytes (50-52).

As mentioned previously, the expression changes that occurred during hypoxia within cardiomyocytes and skeletal myocytes, which both represent tissues of minor importance in respect to systemic iron homeostasis, are very often inconsistent with data previously obtained from the other cell types. In hypoxic conditions, both studied cell lines have demonstrated a decrease in the expression of transferrin receptor and this change was accompanied with a decreased expression of ferroportin gene. Notably, unlike the previous data reporting hypoxia-driven decrement of hepatic hepcidin expression, the present finding demonstrated in both cardiomyocytes and myocytes during hypoxia a markedly increased expression of hepcidin. It is worthwhile mentioning that the function of this iron regulatory hormone locally expressed in the heart and skeletal muscle remains to be fully understood (53-55) and in depth research in this field is required. Furthermore, in skeletal myocytes, the alteration of the expression of iron storage protein, FTH, which was increased in low oxygen was observed. This change may be associated with the potential antioxidant role of FTH in the protective mechanism of myocytes against the hypoxia-mediated generation of reactive oxygen species $(51,52,56)$. 
A

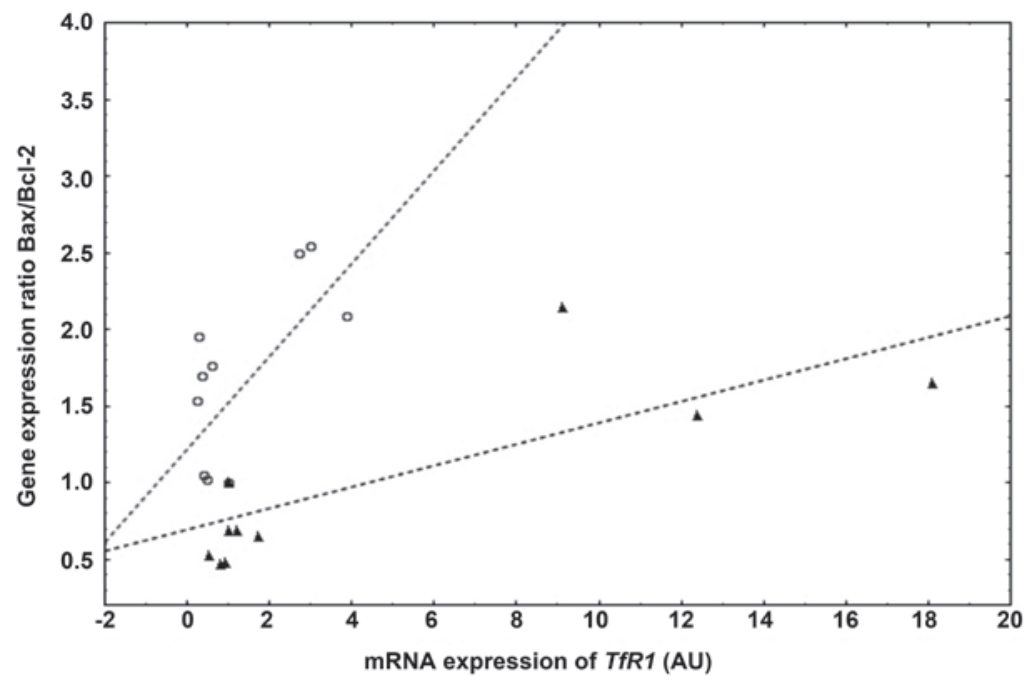

B

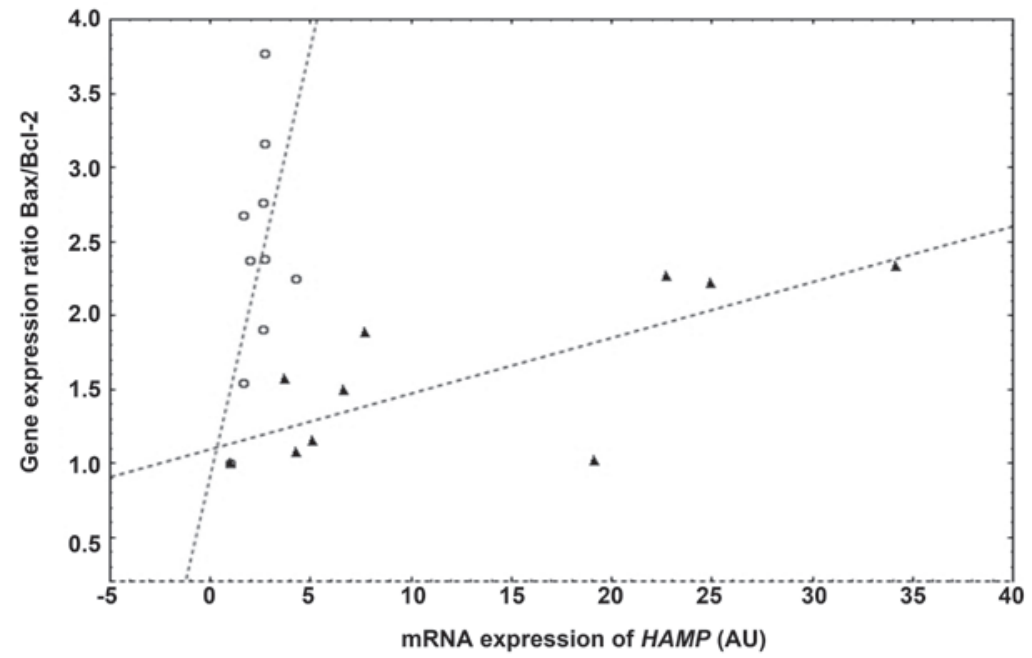

C

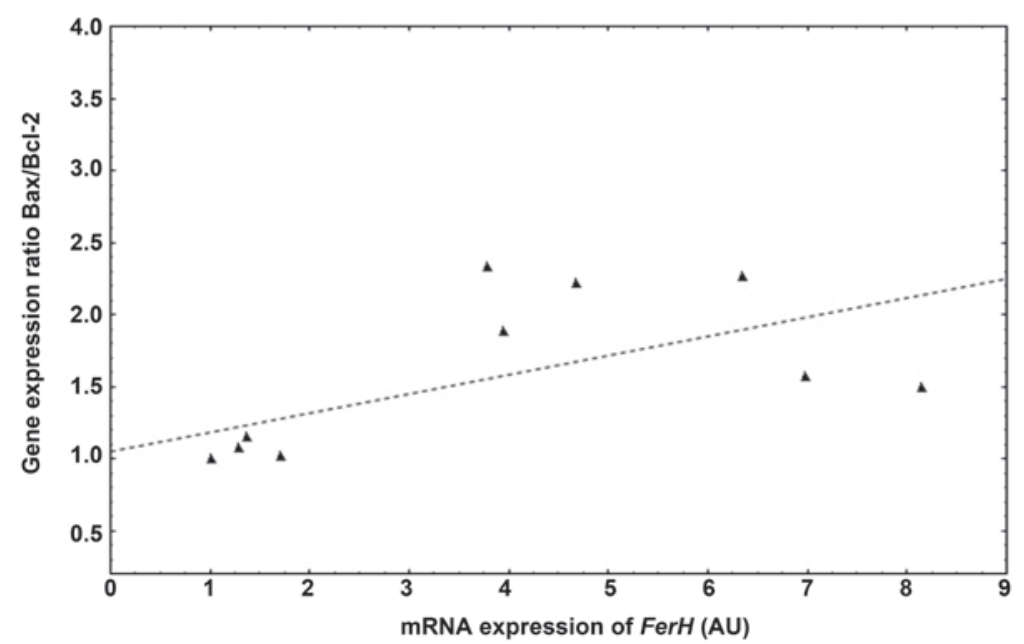

Figure 4. Correlations between the Bax/Bcl-2 ratio in H9C2 (open circle) and L6G8C5 (black triangle) cells, and the expression levels of of (A) TfR1, (B) HAMP and (C) FTH. TfR1, transferrin receptor type 1; FTH, ferritin heavy chain; HAMP, hepcidin; Bcl, B-cell lymphoma; Bax, Bcl-2-asscoiated X protein.

In addition, the present study has demonstrated that the treatment with an iron chelator upon hypoxia resulted in an increased expression of transferrin receptor gene in both cardiomyocytes and myocytes. This finding indicated that the environmental iron depletion, along with low oxygen, may induce an adaptive reaction of the cells, which enables iron resorption. Notably, increased expression of $T f R$ was also demonstrated, reflecting a cellular iron starvation, suggesting an association with the elevated $\mathrm{Bax} / \mathrm{Bcl}-2$ gene expression ratio, thus increased apoptosis. Both cell lines, when exposed to DFO in hypoxia, demonstrated a markedly increased level of $H A M P$ and this change was associated with the elevated $B a x / B c l-2$ gene expression ratio. Therefore, it may be hypothesized that locally expressed hepcidin may account for an 
important agent in stress conditions, including hypoxia and/or iron deficiency.

In the case of skeletal myocytes, several issues are worthy of consideration. Firstly, hypoxia and concomitant either reduced or increase iron availability caused an increased expression of the PKM2 gene, thus, the enhancement of anaerobic glycolysis. This finding suggested that myocytes underwent an oxidative-to-glycolytic shift in the experimental conditions. These observations are consistent with the previously reported data on the influence of hypoxia or iron deficiency on skeletal muscle metabolism $(8,9)$. However, the present study has confirmed that the elevation of iron concentration during hypoxia favors glycolysis to a lesser extent compared with iron limitation. Furthermore, it was demonstrated that in hypoxic conditions the increased iron concentration may be to a certain extent protective since the expression of the marker of muscle atrophy, Atrogin-1, was decreased upon elevated iron availability in comparison with hypoxia alone or hypoxia and iron chelator treatment. Notably, Atrogin-1 expression indicated the imbalance between anabolic and catabolic processes in the myocytes and favored protein breakdown. It appears that during hypoxia the elevated iron availability may suppress muscle atrophy, which results in the loss of muscle mass and leads to muscle weakness, inactivity and increased mortality (36).

Taking together, the present preliminary data suggested that during hypoxia, iron excess is less detrimental for the vitality of cardiomyocytes and skeletal myocytes, compared with in an iron deficiency situation. In addition, it may be hypothesized that the increased availability of iron during hypoxia may be beneficial to a certain extent for skeletal myocytes in the context of preventing muscle atrophy. This premise may stand for a molecular substantiation of the efficacy of iron therapy for the improvement of muscle functional capacity (e.g. in patients with heart failure and concomitant iron deficiency).

Notably, it may be interesting to further investigate the role of the locally expressed hepcidin in cardiomyocytes and skeletal myocytes since the pattern of its expression differs from what has already been explored in hepatocytes.

\section{Acknowledgements}

The present study was supported by a research grant from the Polish Ministry of Science and Higher Education (no. UMO-2012/05/E/NZ5/00590).

\section{References}

1. Ferrari M, Binzoni T and Quaresima V: Oxidative metabolism in muscle. Philos Trans R Soc Lond B Biol Sci 352: 677-683, 1997.

2. Atalay M and Hänninen OOP: Muscle energy metabolism. In Atalay M, Hänninen O (Eds). Encyclopedia of Life Support Systems: Physiology and Maintenance. Vol IV. Eolss Publishers Company Limited: pp26-47, 2009.

3. Stanley WC, Recchia FA and Lopaschuk GD: Myocardial substrate metabolism in the normal and failing heart. Physiol Rev 85: 1093-1129, 2005.

4. Hower V, Mendes P, Torti FM, Laubenbacher R, Akman S, Shulaev V and Torti SV: A general map of iron metabolism and tissue-specific subnetworks. Mol Biosyst 5: 422-443, 2009.

5. Andrews NC: Disorders of iron metabolism. N Engl J Med 341: 1986-1995, 1999.

6. Beard JL: Iron biology in immune function, muscle metabolism and neuronal functioning. J Nutr 131: 568S-579S; discussion 580S, 2001.
7. Galy B, Ferring-Appel D, Sauer SW, Kaden S, Lyoumi S, Puy H, Kölker S, Gröne HJ and Hentze MW: Iron regulatory proteins secure mitochondrial iron sufficiency and function. Cell Metab 12: 194-201, 2010.

8. Ambrose LJ, Abd-Jamil AH, Gomes RS, Carter EE, Carr CA, Clarke K and Heather LC: Investigating mitochondrial metabolism in contracting HL-1 cardiomyocytes following hypoxia and pharmacological HIF activation identifies HIF-dependent and independent mechanisms of regulation. J Cardiovasc Pharmacol Ther 19: 574-585, 2014.

9. Ohlendieck K: Proteomic identification of biomarkers of skeletal muscle disorders. Biomark Med 7: 169-186, 2013.

10. Finch CA, Miller LR, Inamdar AR, Person R, Seiler K and Mackler B: Iron deficiency in the rat. Physiological and biochemical studies of muscle dysfunction. J Clin Invest 58: 447-453, 1976.

11. Davies KJ, Maguire JJ, Brooks GA, Dallman PR, Packer L: Muscle mitochondrial bioenergetics, oxygen supply, and work capacity during dietary iron deficiency and repletion. Am J Physiol 242: E418-E427, 1982.

12. Henderson SA, Dallman PR and Brooks GA: Glucose turnover and oxidation are increased in the iron-deficient anemic rat. Am J Physiol 250: E414-E421, 1986.

13. Thompson $\mathrm{CH}$, Green YS, Ledingham JG, Radda GK and Rajagopalan B: The effect of iron deficiency on skeletal muscle metabolism of the rat. Acta Physiol Scand 147: 85-90, 1993.

14. Ponikowska B, Suchocki T, Paleczny B, Olesinska M, Powierza S, Borodulin-Nadzieja L, Reczuch K, von Haehling S, Doehner W, Anker SD, et al: Iron status and survival in diabetic patients with coronary artery disease. Diabetes Care 36: 4147-4156, 2013.

15. Okonko DO, Mandal AK, Missouris CG and Poole-Wilson PA: Disordered iron homeostasis in chronic heart failure: Prevalence, predictors, and relation to anemia, exercise capacity, and survival. J Am Coll Cardiol 58: 1241-1251, 2011.

16. Jankowska EA, Rozentryt P, Witkowska A, Nowak J, Hartmann O, Ponikowska B, Borodulin-Nadzieja L, Banasiak W, Polonski L, Filippatos G, et al: Iron deficiency: An ominous sign in patients with systolic chronic heart failure. Eur Heart J 31: 1872-1880, 2010.

17. Jankowska EA, Malyszko J, Ardehali H, Koc-Zorawska E, Banasiak W, von Haehling S, Macdougall IC, Weiss G, McMurray JJ, Anker SD, et al: Iron status in patients with chronic heart failure. Eur Heart J 34: 827-834, 2013.

18. Bolger AP, Bartlett FR, Penston HS, O'Leary J, Pollock N, Kaprielian R and Chapman CM: Intravenous iron alone for the treatment of anemia in patients with chronic heart failure. J Am Coll Cardiol 48: 1225-1227, 2006.

19. Toblli JE, Lombraña A, Duarte P and Di Gennaro F: Intravenous iron reduces NT-pro-brain natriuretic peptide in anemic patients with chronic heart failure and renal insufficiency. J Am Coll Cardiol 50: 1657-1665, 2007.

20. Anker SD, Comin Colet J, Filippatos G, Willenheimer R, Dickstein K, Drexler H, Lüscher TF, Bart B, Banasiak W, Niegowska J, et al: Ferric carboxymaltose in patients with heart failure and iron deficiency. N Engl J Med 361: 2436-2448, 2009.

21. Ponikowski P, van Veldhuisen DJ, Comin-Colet J, Ertl G, Komajda M, Mareev V, McDonagh T, Parkhomenko A, Tavazzi L, Levesque V, et al: Beneficial effects of long-term intravenous iron therapy with ferric carboxymaltose in patients with symptomatic heart failure and iron deficiency $†$. Eur Heart J 36: 657-668, 2015.

22. Okonko DO, Grzeslo A, Witkowski T, Mandal AK, Slater RM, Roughton M, Foldes G, Thum T, Majda J, Banasiak W, et al: Effect of intravenous iron sucrose on exercise tolerance in anemic and nonanemic patients with symptomatic chronic heart failure and iron deficiency FERRIC-HF: A randomized, controlled, observer-blinded trial. J Am Coll Cardiol 51: 103-112, 2008.

23. Beck-da-Silva L, Piardi D, Soder S, Rohde LE, Pereira-Barretto AC, de Albuquerque D, Bocchi E, Vilas-Boas F, Moura LZ, Montera MW, et al: IRON-HF study: A randomized trial to assess the effects of iron in heart failure patients with anemia. Int J Cardiol 168: 3439-3442, 2013.

24. Ramey G, Deschemin JC, Durel B, Canonne-Hergaux F, Nicolas G and Vaulont S: Hepcidin targets ferroportin for degradation in hepatocytes. Haematologica 95: 501-504, 2010.

25. Kuriyama-Matsumura K, Sato H, Yamaguchi M and Bannai S: Regulation of ferritin synthesis and iron regulatory protein 1 by oxygen in mouse peritoneal macrophages. Biochem Biophys Res Commun 249: 241-246, 1998.

26. Lok $\mathrm{CN}$ and Ponka P: Identification of a hypoxia response element in the transferrin receptor gene. J Biol Chem 274: 24147-24152, 1999. 
27. Cianetti L, Segnalini P, Calzolari A, Morsilli O, Felicetti F, Ramoni C, Gabbianelli M, Testa U and Sposi NM: Expression of alternative transcripts of ferroportin-1 during human erythroid differentiation. Haematologica 90: 1595-1606, 2005

28. Peyssonnaux C, Nizet V and Johnson RS: Role of the hypoxia inducible factors HIF in iron metabolism. Cell Cycle 7: 28-32, 2008

29. Robach P, Cairo G, Gelfi C, Bernuzzi F, Pilegaard H, Viganò A, Santambrogio P, Cerretelli P, Calbet JA, Moutereau S and Lundby C: Strong iron demand during hypoxia-induced erythropoiesis is associated with down-regulation of iron-related proteins and myoglobin in human skeletal muscle. Blood 109: 4724-4731, 2007.

30. Woo KJ, Lee TJ, Park JW and Kwon TK: Desferrioxamine, an iron chelator, enhances HIF-1alpha accumulation via cyclooxygenase-2 signaling pathway. Biochem Biophys Res Commun 343 : $8-14,2006$.

31. Parkes JG, Hussain RA, Olivieri NF and Templeton DM: Effects of iron loading on uptake, speciation, and chelation of iron in cultured myocardial cells. J Lab Clin Med 122: 36-47, 1993.

32. Hoepken HH1, Korten T, Robinson SR and Dringen R: Iron accumulation, iron-mediated toxicity and altered levels of ferritin and transferrin receptor in cultured astrocytes during incubation with ferric ammonium citrate. J Neurochem 88: 1194-1202, 2004.

33. Sakuragi N, Salah-eldin AE, Watari $H$, Itoh $T$, Inoue $S$, Moriuchi T and Fujimoto S: Bax, Bcl-2, and p53 expression in endometrial cancer. Gynecol Oncol 86: 288-96, 2002.

34. Hanahan D and Weinberg RA: Hallmarks of cancer: The next generation. Cell 144: 646-74, 2011.

35. Aliparasti MR, Alipour MR, Almasi S and Feizi H: Ghrelin administration increases the $\mathrm{Bax} / \mathrm{Bcl}-2$ gene expression ratio in the heart of chronic hypoxic rats. Adv Pharm Bull 5: 195-199, 2015.

36. Bodine SC and Baehr LM: Skeletal muscle atrophy and the E3 ubiquitin ligases MuRF1 and MAFbx/atrogin-1. Am J Physiol Endocrinol Metab 307: E469-E484, 2014.

37. Takenaka M, Noguchi T, Inoue H, Yamada K, Matsuda T and Tanaka T: Rat pyruvate kinase $\mathbf{M}$ gene. Its complete structure and characterization of the 5'-flanking region. J Biol Chem 264: 2363-2367, 1989.

38. Jandl JH, Inman JK, Simmons RL and Allen DW: Transfer of iron from serum iron-binding protein to human reticulocytes. J Clin Invest 38: 161-185, 1959.

39. Donovan A, Lima CA, Pinkus JL, Pinkus GS, Zon LI, Robine S and Andrews NC: The iron exporter ferroportin/Slc40a1 is essential for iron homeostasis. Cell Metab 1: 191-200, 2005.

40. Theil EC: Ferritin: Structure, gene regulation, and cellular function in animals, plants, and microorganisms. Annu Rev Biochem 56: 289-315, 1987.

41. Ganz T: Hepcidin, a key regulator of iron metabolism and mediator of anemia of inflammation. Blood 102: 783-788, 2003.

42. Berridge MV, Herst PM and Tan AS: Tetrazolium dyes as tools in cell biology: New insights into their cellular reduction. Biotechnol Annu Rev 11: 127-152, 2005.
43. Pfaffl MW: A new mathematical model for relative quantification in real-time RT-PCR. Nucleic Acids Res 29: e45, 2001.

44. Walter PB, Knutson MD, Paler-Martinez A, Lee S, Xu Y, Viteri FE and Ames BN: Iron deficiency and iron excess damage mitochondria and mitochondrial DNA in rats. Proc Natl Acad Sci USA 99: 2264-2269, 2002.

45. Ge XH, Wang Q, Qian ZM, Zhu L, Du F, Yung WH, Yang L and Ke Y: The iron regulatory hormone hepcidin reduces ferroportin 1 content and iron release in $\mathrm{H} 9 \mathrm{C} 2$ cardiomyocytes. J Nutr Biochem 20: 860-865, 2009.

46. Parkes JG, Liu Y, Sirna JB and Templeton DM: Changes in gene expression with iron loading and chelation in cardiac myocytes and non-myocytic fibroblasts. J Mol Cell Cardiol 32: 233-246, 2000.

47. Yoon D, Pastore YD, Divoky V, Liu E, Mlodnicka AE, Rainey K, Ponka P, Semenza GL, Schumacher A and Prchal JT: Hypoxia-inducible factor-1 deficiency results in dysregulated erythropoiesis signaling and iron homeostasis in mouse development. J Biol Chem 281: 25703-25711, 2006.

48. Rolfs A, Kvietikova I, Gassmann M, Wenger RH Oxygen-regulated transferrin expression is mediated by hypoxia-inducible factor-1. J Biol Chem 272: 20055-20062, 1997.

49. Tacchini L, Bianchi L, Bernelli-Zazzera A and Cairo G: Transferrin receptor induction by hypoxia. HIF-1-mediated transcriptional activation and cell-specific post-transcriptional regulation. J Biol Chem 274: 24142-24146, 1999.

50. Beaumont C: Molecular mechanisms of iron homeostasis. Med Sci (Paris) 20: 68-72, 2004

51. Cairo G, Tacchini L, Pogliaghi G, Anzon E, Tomasi A and Bernelli-Zazzer A: Induction of ferritin synthesis by oxidative stress. Transcriptional and post-transcriptional regulation by expansion of the 'free' iron pool. J Biol Chem 270: 700-703, 1995.

52. Chandel NS, McClintock DS, Feliciano CE, Wood TM, Melendez JA, Rodriguez AM and Schumacker PT: Reactive oxygen species generated at mitochondrial complex III stabilize hypoxia-inducible factor-1alpha during hypoxia: A mechanism of O2 sensing. J Biol Chem 275: 25130-25138, 2000.

53. Masso-Silva J, Diamond G, Macias-Rodriguez M and Ascencio F: Genomic organization and tissue-specific expression of hepcidin in the pacific mutton hamlet, Alphestes immaculatus (Breder, 1936). Fish Shellfish Immunol 31: 1297-1302, 2011.

54. Merle U, Fein E, Gehrke SG, Stremmel W and Kulaksiz H: The iron regulatory peptide hepcidin is expressed in the heart and regulated by hypoxia and inflammation. Endocrinology 148: 2663-2668, 2007.

55. Przybylowski P, Malyszko J and Malyszko JS: A possible role of hepcidin in the pathogenesis of anemia in heart allograft recipients. Transplant Proc 42: 1803-1807, 2010.

56. Smith JJ, O'Brien-Ladner AR, Kaiser CR and Wesselius LJ: Effects of hypoxia and nitric oxide on ferritin content of alveolar cells. J Lab Clin Med 141: 309-317, 2003. 